\title{
Water stress in germination, growth and development of coffee cultivars ${ }^{1}$
}

\author{
Julieta Andréa Silva de Almeida ${ }^{2 *}$, Mary Túlia Vargas Lobato Guedes de Azevedo², \\ Marcus Vinicius Salomon ${ }^{3}$, Priscila Fratin Medina ${ }^{2}$
}

\begin{abstract}
The aim of this study was to evaluate the effect of water stress on the germination of Coffea arabica seeds and the growth and development of plants from these seeds. Seeds of the cultivars Bourbon Vermelho, Mundo Novo, and BA-10 were placed to germinate in the dark at $30^{\circ} \mathrm{C}$ in the presence and absence of $100 \mathrm{~g} / \mathrm{L}$ of polyethylene glycol 6000 . The water stress applied delayed the beginning of seed germination by seven days in relation to seeds of the control, which had achieved responses of up to $50 \%$, but there were no differences between the treatments at the end of the experiment. Furthermore, the length of the primary root in seeds germinated under water stress was less than in the control treatment, especially for the cultivar Mundo Novo. Plants of the cultivars Bourbon Vermelho and Mundo Novo developed from seeds previously germinated under water stress exhibited reduced height and fewer leaf pairs than those from the control, whereas 'BA-10' responded in a similar way in both treatments. Thus, the cultivars Bourbon Vermelho and Mundo Novo were more sensitive to the water stress applied in the germination phase than 'BA-10'.
\end{abstract}

Index terms: Coffea arabica, biometrics, BA-10, Bourbon Vermelho, Mundo Novo, PEG 6000.

\section{Estresse hídrico na germinação, crescimento e desenvolvimento de cultivares de cafeeiro}

\begin{abstract}
RESUMO - O objetivo deste estudo foi avaliar o efeito do estresse hídrico na germinação de sementes de Coffea arabica e o crescimento das plantas provenientes destas. Sementes das cultivares Bourbon Vermelho, Mundo Novo e BA-10 foram colocadas para germinar na presença e ausência de $100 \mathrm{~g} / \mathrm{L}$ de Polietilenoglicol 6000, no escuro, a $30^{\circ} \mathrm{C}$. O estresse hídrico aplicado atrasou o início da germinação das sementes em sete dias em relação àquelas do controle que tinham atingido respostas de até $50 \%$, porém não houve diferenças entre os tratamentos no final do experimento. Além disto, as sementes germinadas sob estresse hídrico tiveram redução do comprimento da raiz primária em relação àquelas do controle, principalmente, para o Mundo Novo. Plantas das cultivares Bourbon Vermelho e Mundo Novo desenvolvidas a partir das sementes previamente germinadas sob estresse hídrico tiveram redução da altura e do número de pares de folhas em comparação com aquelas provenientes do controle, enquanto a cultivar BA-10 respondeu de forma semelhante nos dois tratamentos. Assim, as cultivares Bourbon Vermelho e Mundo Novo foram mais sensíveis ao estresse hídrico aplicado na fase de germinação que o 'BA-10'.
\end{abstract}

Termos para indexação: Coffea arabica, biometria, BA-10, Bourbon Vermelho, Mundo Novo, PEG 6000.

\section{Introduction}

The coffee crop is of considerable importance in Brazilian

${ }^{1}$ Submitted on 03/06/2017. Accepted for publication on 01/11/2018. ${ }^{2}$ Instituto Agronômico de Campinas (IAC), Centro de Café 'Alcides Carvalho', Av. Barão de Itapura, 1481, Vila Itapura, 13020-902 - Campinas, SP, Brasil. agricultural production, but its hegemony may be threatened by increasing temperature from global warming, which changes rainfall patterns, causing the phenomena of a great deal of rain

${ }^{3}$ Coordenadoria de Assistência Técnica Integral (CATI), Departamento de Extensão Rural, Av. Brasil, 2340, Jardim Brasil, 13070-178 - Campinas, SP, Brasil.

${ }^{*}$ Corresponding author $<$ julietasa@iac.sp.gov.br> 
in some regions and of drought in others (Leandro, 2013).

Drought conditions significantly limit the growth and development of Coffea plants (Matta et al., 2008), which leads to reduced yield (Kobayashi et al., 2008; Nascimento et al., 2008). Nevertheless, the losses caused by this stress factor can be minimized by the development of cultivars tolerant to lack of water (Vadez et al., 2013). The C. arabica species have a wide diversity of genotypes, and those with drought tolerance can be incorporated as a source of resistance in creating new cultivars. A breeding program requires 30 years to release a new coffee cultivar, and intermediate selection of genotypes of interest is normally performed in plants that are five to six years old (Medina-Filho et al., 2008). This prolonged time could be reduced if selection were carried out in individuals in a younger stage of development, such as seeds. In breeding of different species, responses of seed germination have been considered in selection of genotypes tolerant and/or sensitive to drought (Almaghrabi, 2012); however, this aspect has not yet been examined for the coffee crop.

The germination process consists of two main phases: the physical phase that corresponds to imbibition of water by seeds, followed by metabolic activities that lead to radicle protrusion (Nonogaki et al., 2010). In imbibition, reactivation of already existing organelles and macromolecules occurs, followed by the growth and cell division phase. The germination process of $C$. arabica is normally slow; seeds generally begin responding after a week of imbibition and achieve maximum response on the 14th day (Farias et al., 2015; Hilst et al., 2016; Adepoju et al., 2017).

Seed germination can be affected by biotic and abiotic factors (Ambede et al., 2012). The response to any type of stress is related to the application of an external factor that exercises a detrimental influence on the metabolism of the plant tissue, causing injury, disease or physiological abnormalities (Jaleel et al., 2009). Plants subjected to lack of water may exhibit different models of perception of this stress factor, which may be modulated by the trait of drought tolerance belonging to each species. Individual cells of an organ under water restriction show changes in volume, accompanied by modifications in water and osmotic potential (Feng et al., 2016). The condition of lack of water at germination may delay primary root protrusion, reduce the percentage of seeds that complete the process, or completely inhibit germination (Velázquez-Márquez et al., 2015). Farrant and Moore (2011) also discuss that plants have tolerance to desiccation, a mechanism that allowed them to be established on land. However, responses can vary among different types of plant tissues; seeds characteristically have greater tolerance to lack of water. The changes brought about by water stress will depend on its intensity and duration and the genotype and phenological stage of the plant (Santos and Carlesso, 1998; Muscolo et al., 2014).

$C$. arabica seeds have been identified as sensitive to desiccation (Eira et al., 2006). Characterization of responses of germination under water stress frequently involve imbibition of seeds in a solution of known water potential, which can delay or completely inhibit germination. In the laboratory, water stress can be simulated by the addition of osmotic agents in the seed substrate, such as polyethylene glycol 6000 (PEG 6000) solution. Hardegree and Emmerich (1994) found that physical contact between the seed surface of six grass cultivars and the PEG solution was sufficient to induce water stress in them. In addition, PEG 6000 has been used in germination studies since it is chemically inert and nontoxic to seeds; it simulates drought conditions; and it does not penetrate the seed coat, due to the size of its molecule (Ahmad et al., 2007; Almeida et al., 2014; Liu et al., 2017). PEG induces a more negative water potential, impeding or reducing water absorption by seeds (Bonvissuto and Busso, 2007; Verslues and Juenger, 2011). This system has been found to be applicable to diverse species (Mantovani and Iglesias, 2010; Martins et al., 2012; Pelegrini et al., 2013; Li et al., 2013; Refka et al., 2013).

The aim of this study was to verify the effect of water stress induced by PEG 6000 on germination of $C$. arabica L. seeds and characterize its influence on initial growth and development of the plants.

\section{Materials and Methods}

In May 2013, seeds were taken from fruit in the cherry stage collected from adult plants of $C$. arabica from the cultivars Bourbon Vermelho, Mundo Novo and BA-10 belonging to the germplasm of the Instituto Agronômico de Campinas, Campinas, SP, Brazil. The seeds used had a $10 \%$ moisture content. First, the parchment was removed from the seeds to set up the experiment. Soon after, the seeds without parchment were disinfected in commercial sodium hypochlorite $(2.5 \%)$ for 15 minutes; they were washed three times in distilled water and then received the fungicide Derosol (2 $\mathrm{mL} / \mathrm{Kg}$ of seed).

Gerbox plastic boxes were used in the experiment. These boxes were previously disinfected with commercial sodium hypochlorite for 24 hours. They were then lined with a sheet of filter paper. To each box $12 \mathrm{~mL}$ of distilled water and/or $12 \mathrm{~mL}$ of PEG 6000 solution were added at a concentration of $100 \mathrm{~g} / \mathrm{L}$. The boxes with the seeds were kept in a B.O.D. growth chamber under a temperature of $30{ }^{\circ} \mathrm{C}$ in the absence of light. To control moisture loss, the 
Gerbox boxes with the seeds were weighed weekly, followed by replacement of water lost by evaporation and they were kept within transparent polyethylene bags. The seeds were evaluated weekly in regard to the occurrence of germination. The biological criterion, radicle protrusion, was adopted for that purpose. Primary root length of the germinated seeds was determined in all the treatments at 30 days after the beginning of germination. At the end of the germination phase, seeds with the presence of the primary root in all the treatments were transplanted to plastic pots $(500 \mathrm{~mL})$ with a substrate composed of a mixture of soil, sand and coconut fiber (3:1:1), which were kept in a greenhouse. Each treatment consisted of 30 replications. The seedlings developed from these seeds were evaluated weekly over two months in regard to their stage of development. attributing the following scores: 1. 'palito de fósforo' (Matchstick) (straightened hypocotyl with seed above the soil in remains of the endosperm), 2. 'orelha de onça'(cotyledonar stage) (expanded cotyledonary leaves) and 3. seedling (plant with leaf pairs). In Brazil the terms 'palito de fósforo' and 'orelha de onça' are used conventionally for the coffee crop. After that, these seedlings were transplanted individually in plastic pots $(1.5 \mathrm{~L})$, with the same substrate used before and evaluated in regard to plant shoot height and the number of leaf pairs formed.

A completely randomized experimental design was used in a $3 \times 2$ factorial arrangement consisting of three cultivars, Mundo Novo, Bourbon Vermelho and BA-10 and two concentrations of PEG 6000, 0 and $100 \mathrm{~g} / \mathrm{L}$, with four replications of 50 seeds per treatment. The germination percentage data were transformed into arcsene of the square root before statistical analysis. The results of radicle length, plant shoot height and number of leaf pairs were subjected to analysis of variance and the mean values of these variables were compared by the Tukey test at $5 \%$ probability.

\section{Results and Discussion}

Water stress induced by $100 \mathrm{~g} / \mathrm{L}$ of PEG 6000 delayed the beginning of germination of seeds from three cultivars of $C$. arabica by seven days, whereas seeds of the control treatment had already achieved up to $50 \%$ germination (Figure 1). However, from the 14th day on, differences were not observed among the treatments, which achieved a high rate of germination, around $70 \%$. These results may be related to the observations that the more negative water potential tended to inhibit or delay germination of seeds from different species (Rego et al., 2007; Mohammdkhani and Heidari, 2008; Abdel-Ghani et al., 2015; Arcoverde et al., 2017). The influence of PEG on delaying the beginning of germination is also found in other species, such as in seeds of two cultivars of Pinus sylvestris that did not respond in treatment with PEG 6000 above $25 \%$, or delayed the beginning of germination by 2 to 4 days in response to $20 \%$, or by one day at rates of $10 \%$ to $15 \%$ (Zhu et al., 2006). The response of the three cultivars is also similar to the results obtained by Mantovani and Iglesias (2010) of seeds of three species of Bromelia subjected to different rates of PEG 6000 that exhibited delay in beginning germination, and, at the end of the experiment, the differences among the treatments disappeared. In addition, preliminary results of this study indicated that concentrations

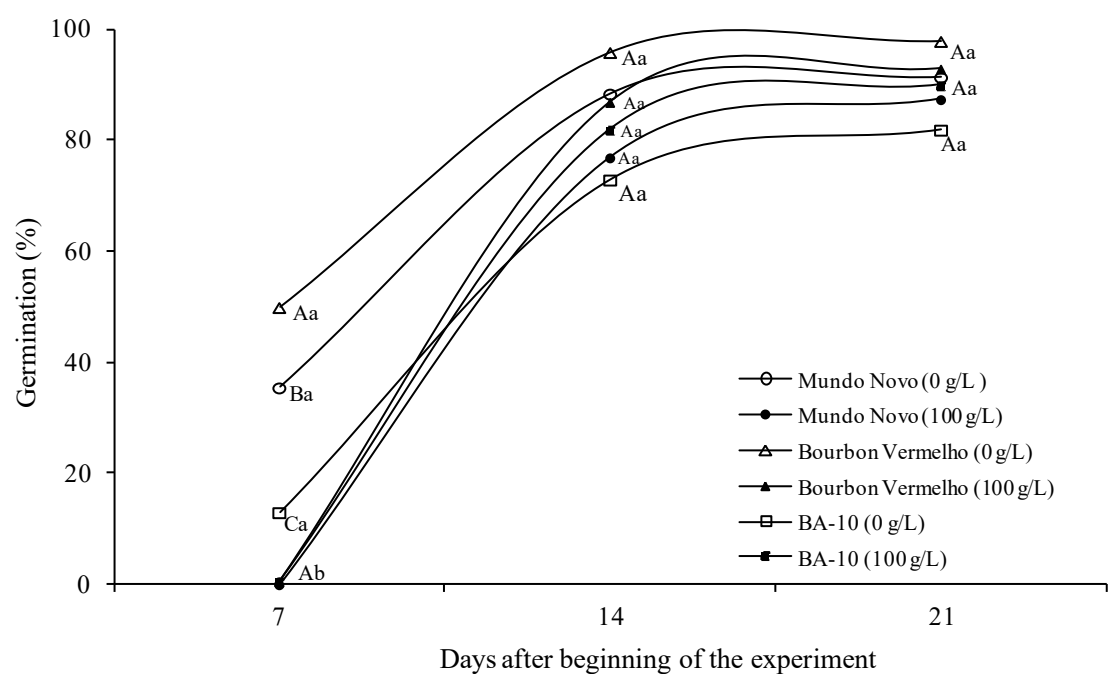

Figure 1. Germination of seeds of three cultivars of C. arabica in substrate with the addition of PEG 6000 solution in the absence of light and at $30{ }^{\circ} \mathrm{C}$. On the day of evaluation: uppercase letters represent significant differences among the genotypes. Lowercase letters represent significant differences among the concentrations of PEG 6000. 
of PEG 6000 less than $100 \mathrm{~g} / \mathrm{L}$ had little influence on the germination process of seeds from the three cultivars studied (data not shown). However, it is possible that PEG 6000 concentrations above $100 \mathrm{~g} / \mathrm{L}$ may lead to differentiated responses in tolerance to lack of water among these cultivars.

Another aspect related to the water stress applied is in regard to its intensity, which may be classified as low since it did not interfere with the occurrence of germination of the seeds of the three cultivars of C. arabica. But, in spite of that, the seeds were sensitive to the water stress applied since they responded by delaying one week in relation to the control treatment. Furthermore, the seeds of the three cultivars under water stress had similar germination responses, but this was different in the control treatment, since Bourbon Vermelho had a higher response, 50\%, followed by Mundo Novo, 35\%, and a reduced response for BA-10, 13\% (Figure 1). Thus, in the control treatment, each cultivar exhibited a different pattern of germination, while under water stress, the seeds had standardization of the responses. In this case, standardization of germination suggests some relationship to osmoconditioning or priming, a process that may be induced by the PEG, which is used to optimize and synchronize responses of seeds that have difficulties in germination (Dantas et al., 2010; José et al., 2016). Abdel-Ghani et al. (2015) also found that barley seeds had osmoconditioning responses when exposed to $15 \%$ and $18 \%$ PEG 6000 , through achieving a higher rate of germination than those of the control.

Seeds subjected to any alteration of water potential of the substrate may exhibit difficulties in absorbing water (Jaleel et al., 2009; Reis et al., 2012; Abdel-Ghani et al., 2015). Although the water stress applied was of low intensity, the seeds of the three cultivars of $C$. arabica may have used some biochemical or morphological strategy over the first seven days to avoid loss of water, achieving a situation of equilibrium that allowed germination. For Farrant and Moore (2011) seeds in general exhibit greater tolerance to lack of water than other types of tissues or other stages of plant development. However, greater examination of this matter would be important to identify the possible strategies used by the seeds of the three cultivars to avoid water loss, keeping in mind that they remained in contact with the PEG 6000 solution while germination was carried out.

The seeds of the Coffea cultivars were also evaluated in relation to the length of the primary roots, which were lower under water stress than those of the control treatment, especially for the cultivar Mundo Novo (Figure 2). The length of the primary root was $22 \mathrm{~mm}$ for Mundo Novo, $30.1 \mathrm{~mm}$ for Bourbon Vermelho and $29.9 \mathrm{~mm}$ for BA-10, while the mean length for the control was $33 \mathrm{~mm}$. This type of response is also found in other species, such as in two cultivars of Pinus treated with PEG; the length of the roots increased for cv. Natural, whereas decreased for cv. Plantation (Zhu et al., 2006). Normally, plants under water stress come to develop longer roots than those under continuous hydration (Matta et al., 2008), which is understood to be an adaptation to this condition. Longer roots are associated with greater extraction of water from deeper areas of the soil, which alleviates the effects of drought conditions (Vadez, 2014). Nevertheless, the lower growth of the primary roots of the seeds of the three cultivars under water stress may be related to the fact

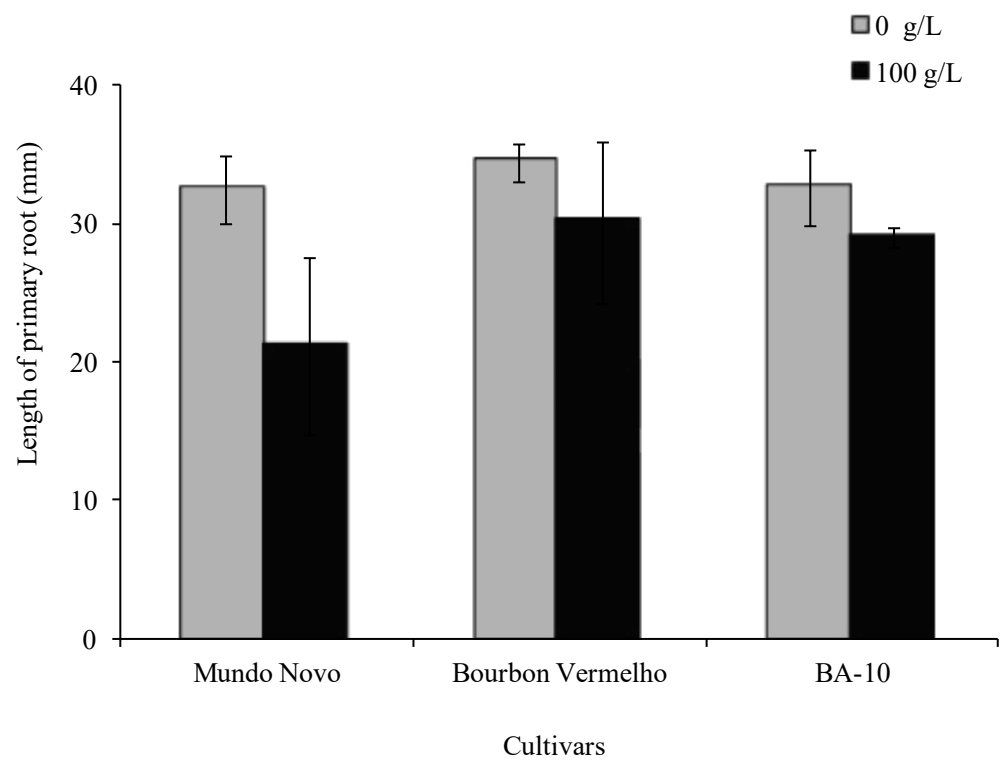

Figure 2. Length of the primary root of seeds of three C. arabica cultivars germinated in substrate with the addition of PEG 6000 solution and kept in the absence of light under the temperature of $30^{\circ} \mathrm{C}$. 
that, in this phase, they were in the initial process of formation, i.e., they had not completed their development. That way, they would not be capable of supporting the impact of lack of water. Perhaps if they were more developed, they could respond with roots of greater length.

At the end of the germination process, seeds with a primary root from all the treatments were transplanted to pots kept in a greenhouse, and after two months, they were evaluated in relation to their stages of development (Figure 3). Normally, germinated C. arabica seeds pass through the 'palito de fósforo' (matchstick), 'orelha de onça' (cotyledonar stage) and seedling phenological stages. In this evaluation, the seedlings of the cultivars Mundo Novo and Bourbon Vermelho from seeds germinated under water stress had a greater percentage of individuals in the 'palito de fósforo' stage than those of the control, as shown in Figures 3A and 3B, respectively. In the seedlings from seeds of the control treatment, there is higher occurrence of the 'orelha de onça' and seedling stages, indicating that they developed more than those from the treatments under water stress. Nevertheless, for the cultivar BA-10, there was a different standard of response since there was predominance of a high percentage of the 'palito de fósforo' type, around $60 \%$, among the seedlings from the seeds germinated under water stress and from the control (Figure 3C). Afterwards, when these seedlings reached the plant stage, they were evaluated in relation to height and the number of leaf pairs formed (Figure 4). Mundo Novo and Bourbon Vermelho plants coming from seeds germinated under water stress had responses of lower height and reduced number of leaf pairs compared to plants from the control, as shown in Figures 4A, 4B, 4D, and 4E, whereas for BA-10, height and number of leaf pairs were once again similar in both treatments (Figures $4 \mathrm{C}$ and $4 \mathrm{~F}$ ). These responses indicate that although germination of the seeds of Bourbon Vermelho and Mundo Novo were not strongly affected by water stress, this treatment caused some change that was expressed in the plant stage, impairing the growth and development of the seeds. This aspect indicates that these two cultivars were sensitive to lack of water induced by the treatment with $100 \mathrm{~g} / \mathrm{L}$ of PEG 6000 . In contrast, the cultivar BA-10 proved to be indifferent to the stress applied in the germination phase since the plants coming from seeds germinated under this condition had development similar to plants of the control treatment. Plants can be affected by drought in any phenological stage; however, some of these stages are more critical, such as germination (Farroq et al., 2012). Considering the performance of BA-10, which proved to be somewhat indifferent to the effect of water stress applied at germination, this aspect may be related to the study of Mazzafera and Carvalho (1987), who classified plants of this cultivar and of its hybrids in the field as drought tolerant since it showed high yield in this situation. However, the results obtained in the present study are preliminary since they are related to the effect of $100 \mathrm{~g} / \mathrm{L}$ of PEG 6000 . Other concentrations may make different contributions in regard to the drought tolerance of these cultivars.

A Mundo Novo

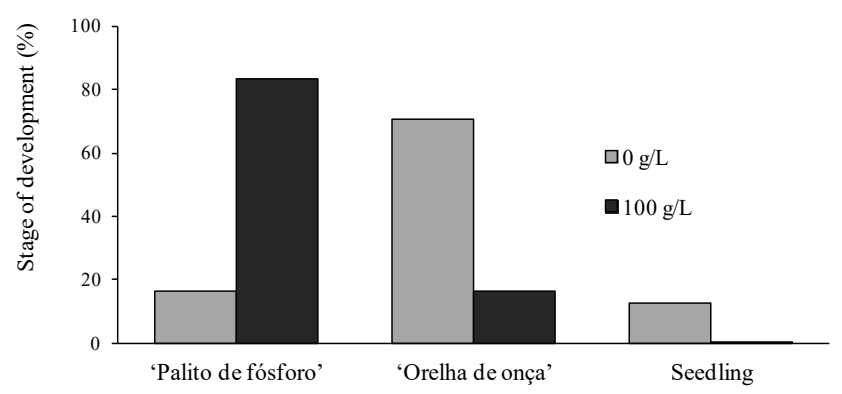

B Bourbon Vermelho

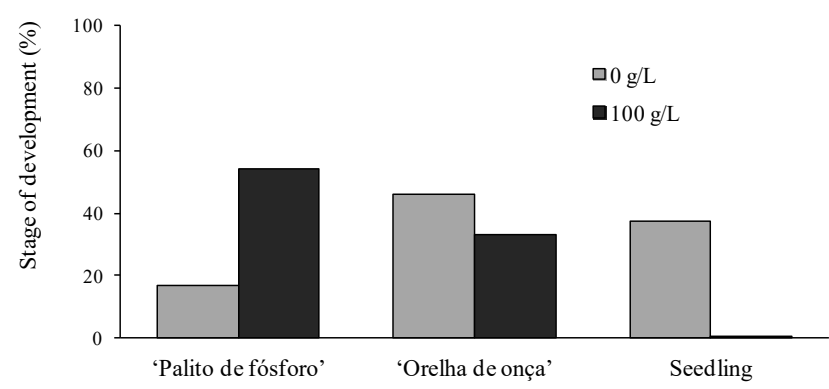

C BA-10

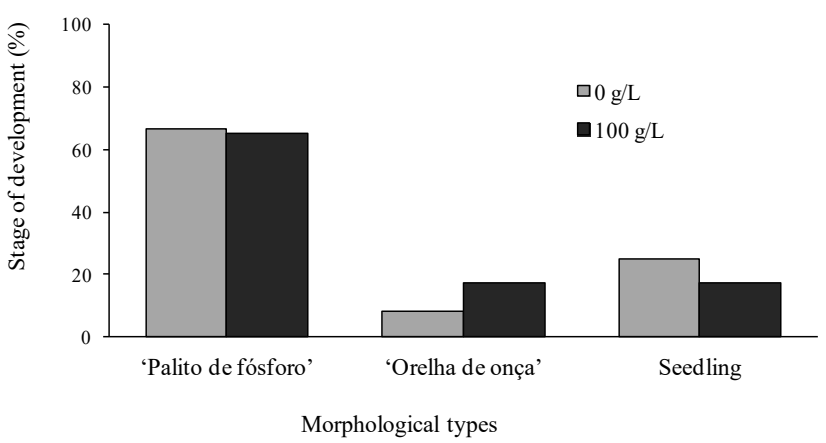

Figure 3. Percentage of stages of development in seedlings of three $C$. arabica cultivars coming from seeds germinated in substrate with the addition of PEG 6000 two months after individual transplanting in $500 \mathrm{~mL}$ pots in a greenhouse and under natural lighting. 'Palito de fósforo': Matchstick, 'Orelha de onça': Cotyledonar stage. 
A

Mundo Novo

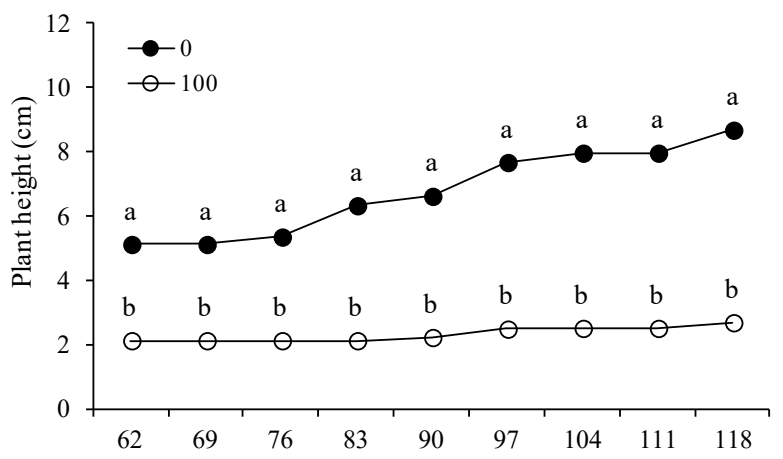

B

Bourbon Vermelho

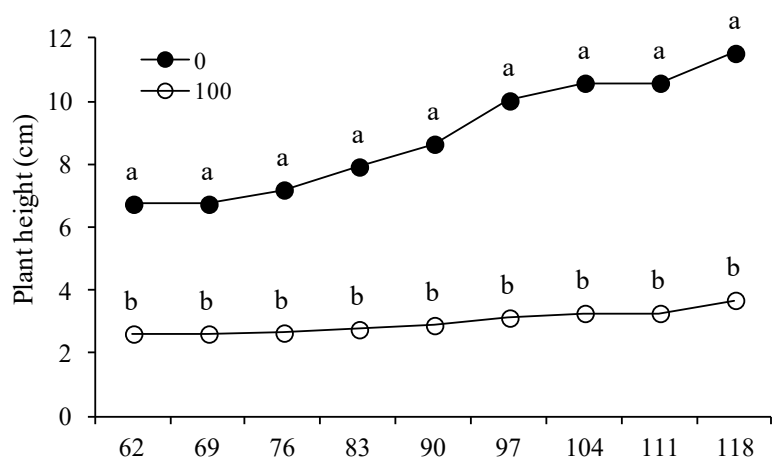

C

BA-10

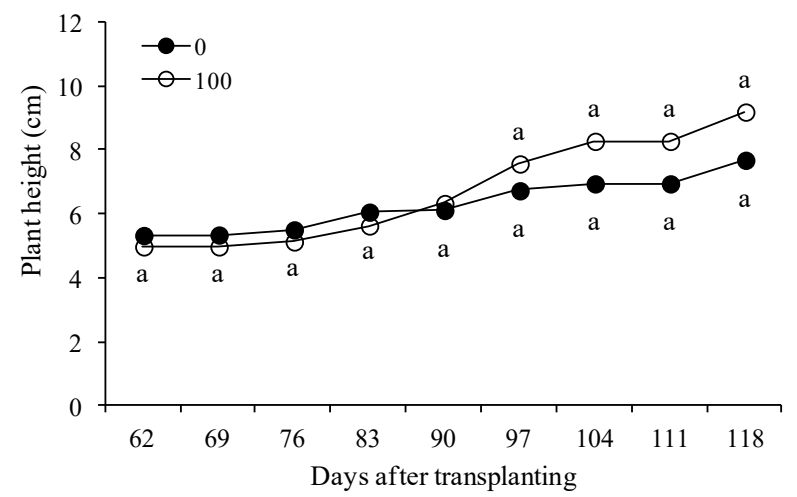

$\mathrm{D}$

Mundo Novo

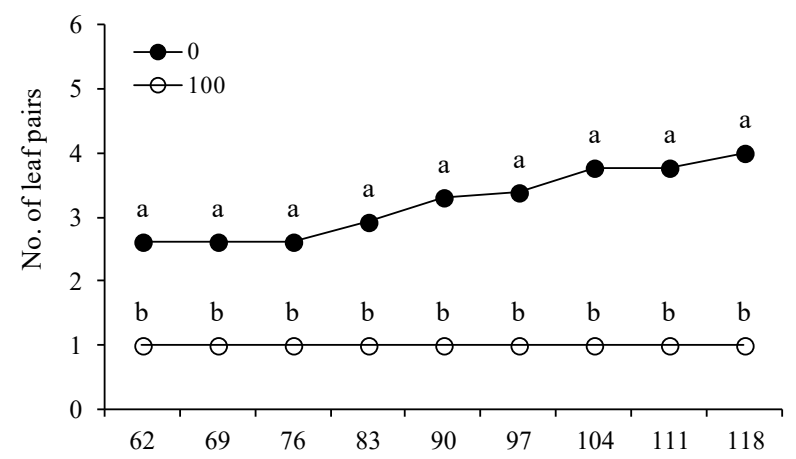

E

Bourbon Vermelho

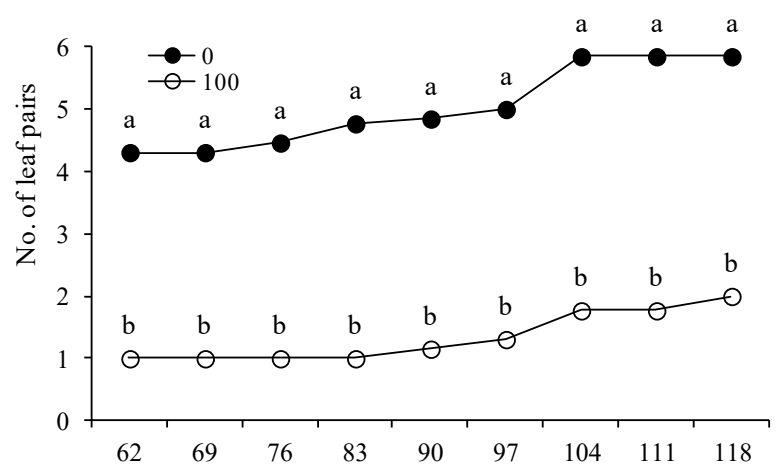

F

BA-10

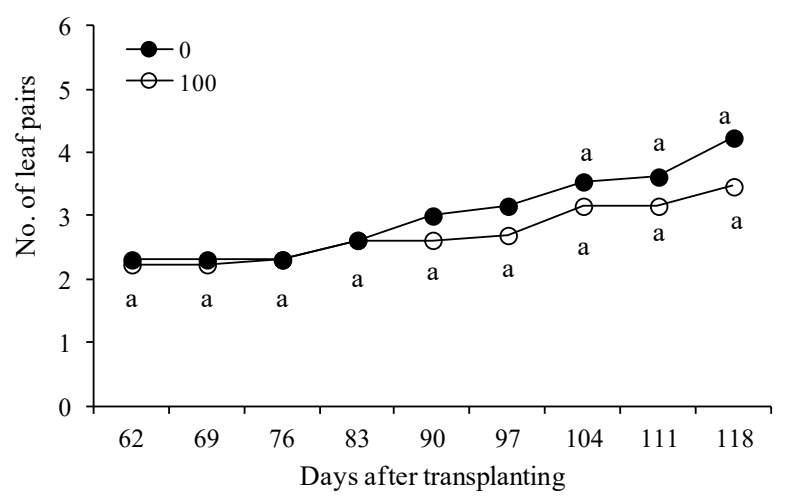

Figure 4. Characterization of the height and of the number of leaf pairs in plants of different cultivars of $C$. arabica, coming from seeds previously germinated in substrate with the addition of PEG 6000 after individual transplanting to $1.5 \mathrm{~L}$ pots in a greenhouse under natural lighting. Different letters on the same day of evaluation indicate statistical difference among the treatments.

\section{Conclusions}

Water stress delays the beginning of germination of $C$. arabica seeds in relation to the control treatment.
The cultivars Bourbon Vermelho and Mundo Novo are more sensitive to water stress applied in the germination phase than the cultivar BA-10.

The initial growth and development of the plants of the 
cultivars Bourbon Vermelho and Mundo Novo are impaired by water stress applied in the germination phase, whereas this not affect the cultivar BA-10.

\section{Acknowledgments}

Our thanks to the Consórcio de Pesquisa Café.

\section{References}

ABDEL-GHANI, A.H.; NEUMANN, K.; WABILA, C.; SHARMA, R.; DHANAGOND, S.; OWAIS, S.J. Diversity of germination and seedling traits in a spring barley (Hordeum vulgare L.) collection under drought simulated conditions. Genetic Resources Crop Evolution, v.62, p.275-292, 2015. https://link.springer.com/ article/10.1007/s10722-014-0152-z/fulltext.html.

ADEPOJU, A.F.; ADENUGA, O.O.; MAPAYI, E.F.; OLANIYI, O.O.; ADEPOJU, F.A. Coffee: botany, distribution, diversity, chemical composition and its management. Journal Agriculture and Veterinary Science, v.10, p.57-62, 2017.http://www.iosrjournals.org/ iosr-javs/papers/Vol10-issue7/Version-3/I1007035762.pdf.

AHMAD, M.S.A.; JAVED, F.; ASHRAF, M. Iso-osmotic effect of $\mathrm{NaCl}$ and PEG on growth, cations and free proline accumulation in callus tissue of two indica rice (Oryza sativa L.) genotypes. Plant Growth Regulation, v.53, p.53-63, 2007. https://link.springer.com/ content/pdf/10.1007\%2Fs10725-007-9204-0.pdf

ALMAGHRABI, O.A. Impact of drought stress on germination and seedling growth parameters of some wheat cultivars. Life Science Journal, v.9, p.590-598, 2012. http://www.lifesciencesite.com/lsj/li fe0901/087_8160life0901_590_598.pdf.

ALMEIDA, J.P.N.; PINHEIRO, C.L.; LESSA, B.F.T.; GOMES, F.M.; MEDEIROS FILHO, S. Estresse hídrico e massa de sementes na germinação e crescimento de plântulas de Amburana cearensis (Allemão) A.C. Smith. Revista Ciência Agronômica, v.45, p.777787, 2014. http://www.seer.ufv.br

AMBEDE, J.G.; NETONDO, G.W.; MWAI, G.N.; MUSYIMI, D.M. $\mathrm{NaCl}$ salinity affects germination, growth, physiology and biochemistry of bambara groundnut. Brazilian Journal Plant Physiology, v.24, p.151-160, 2012. http://www.scielo.br/pdf/bjpp/v24n3/02.pdf.

ARCOVERDE, S.N.S.; MARTINS, E.A.S.; MELO, R.M.; HARTMANN FILHO, C.P.; GORDIN, C.R.B. Germinação e crescimento de plântulas de Niger sob diferentes disponibilidades hídricas do substrato e regimes de luz. Revista Engenharia na Agricultura, v.25, p.344-353, 2017. http://www.seer.ufv.br

BONVISSUTO, G.L.; BUSSO, C.A. Germination of grasses and shrubs under various water stress and temperature conditions. Revista Internacional de Botanica Experimental, v.76, p.119-131, 2007. http://www.scielo.org.ar/pdf/phyton/v76/v76a11.pdf.

DANTAS, I.B.; GUIMARÃES, R.M.; VON PINHO, E.V.R.; CARVALHO, M.L.M. Osmotic priming methodologies in relation to the physiological performance of rangpur lime seeds (Citrus limonia Osbeck). Revista Brasileira de Sementes, v.32, p.141-151, 2010. http://www.scielo.br/pdf/rbs/v32n3/v32n3a16.pdf.
EIRA, M.T.S.; SILVA, E.A.A; CASTRO, R.D.; DUSSERT, S.; WALTERS, C.; DEREK BEWLWY, J.; HILLORST, H.W.M. Coffee seed physiology. Brazilian Journal Plant Physiology, v.18, p.149163, 2006. http://www.scielo.br/pdf/bjpp/v18n1/a11v18n1.pdf.

FARIAS, E.T; SILVA, E.A.A.; TOOROP, P.E.; BEWLEY, J.D.; HILHORST, H.W.M. Expression studies in the embryo and in the micropylar endosperm of germinating coffee (Coffea arabica cv. Rubi) seeds. Plant Growth Regulation, v.75, p.575-581, 2015. http:// link.springer.com/article/10.1007\%2Fs10725-014-9960-6.

FAROOQ, M.; HUSSAIN, M.; WAHID, A.; SIDDIQUE, K.H.M. Drought stress in plants: An Overview, Chapter 1. IN: AROCA, R. (ED). Plant Responses to Drought Stress, Berlin Heidelberg:SpringerVerlag, 2012. p. 1-5.

FARRANT, J.M.; MOORE, J.P. Programming desiccation-tolerance: from plants to seeds to resurrection plants. Current Opinion in Plant Biology, v.14, p.340-345, 2011. http://www.sciencedirect.com/science?_ob=ArticleListURL\&_method=list\&_ArticleListID $=-1168486025 \&$ sort $=$ r\&_ $\mathrm{st}=13 \&$ view $=\mathrm{c} \& \mathrm{md} 5=3 \mathrm{e} 052 \overline{\mathrm{d}} 959 \mathrm{dbc} 6765274 \mathrm{~b} 580 \mathrm{ad} 07 \mathrm{~d} 82 \mathrm{e} 5$ \&searchtype $=$ a.

FENG, W.; LINDNER, H.; ROBBINS, N.E.; DINNENYA, J.R. Growing out of Stress: The role of cell and organ-scale growth control in plant water-stress responses. The Plant Cell, v.28, p.1769-1782, 2016. http://www.plantcell.org/content/28/8/1769.full.pdf + html

HARDEGREE, S.P.; EMMERICH, W.E. Seed germination response to polyethylene glycol solution depth. Seed Science \& Technology, v.22, p.1-7, 1994. http://www.seedtest.org/en/content---1--1084.html

HILST, P.C.; DIAS, D.C.F.S.; GAMA, G.F.V.G.; ARAÚJO, J.O. Exudate coloring test suitability for assessing the viability of coffee seeds (Coffea arabica L.). Journal of Seed Science, v.38, p.212-218, 2016. http://dx.doi.org/10.1590/2317-1545v38n3162923

JALEEL, C.A.; MANIVANNA, P.; WAHID, A.; FAROOQ, M.; AL-JUBURI, J.; SOMASUNDARAM, R.; PANNEERSELVAM, R. Drought stress in plants: A review on morphological characteristics and pigments composition. International Journal of Agriculture \& Biology, v.11, p.100-105, 2009. http://www.fpublishers.org.

JOSÉ, A.C.; SILVA, N.C.N.; FARIA, J.M.R.; PEREIRA, W.V.S. Influence of priming on Eucalyptus spp seeds' tolerance to salt stress. Journal of Seed Science, v.38, p.329-334, 2016. http://dx.doi. org/10.1590/2317-1545v38n4165060

KOBAYASHI, E.S.; SAKAI, E.; SILVA, E.A.; ARRUDA, F.B.; SILVEIRA, J.M.C; SOUZA, P.S.; PIRES, R.C.M. Variação sazonal do potencial da água nas folhas de cafeeiro em Mocóca, SP. Bragantia, v.67, p.421-428, 2008.

LEANDRO, C.A.R. Estudo das consequências do aquecimento global na produção agrícola. Revista Especialize On-line IPOG, v.6, 2013. https://www.ipog.edu.br/download-arquivo-site.sp.

LI, H.; LI, X.; ZHANG, D.; LIU, H.; GUAN, K. Effects of drought stress on the seed germination and early seedling growth of the endemic desert plant Eremosparton songoricum (Fabaceae). EXCLI Journal, v.12, p.89-101, 2013. https://www.ncbi.nlm.nih.gov/pmc/ articles/PMC4531793/pdf/EXCLI-12-89.pdf. 
LIU, Y.; MENG, Q.; DUAN, X.; ZHANG, Z.; LI, D. Effects of PEGinduced drought stress on regulation of indole alkaloid biosynthesis in Catharanthus roseus. Journal Plant Interactions, v.12, p.87-91, 2017. https://doi.org/10.1080/17429145.2017.1293852

MANTOVANI, A.; IGLESIAS, R.R. The effect of water stress on seed germination of three terrestrial bromeliads from resting. Revista Brasileira de Botânica, v.33, p.201-205, 2010. http:/www.scielo.br/ $\mathrm{pdf} / \mathrm{rbb} / \mathrm{v} 33 \mathrm{n} 1 / 17$.pdf.

MARTINS, L.S.T.; PEREIRA, T.S.; CARVALHO,A.S.R.; BARROS, C.F.; ANDRADE, A.N.S. Seed germination of Pilosocereus arrabidae (Cactaceae) from a semiarid region of south-east Brazil. Plant Species Biology, v.27, p.191-200, 2012. http://onlinelibrary. wiley.com/doi/10.1111/j.1442-1984.2011.00360.x/epdf

MATTA, F.M.; RENA, A.B.; CARVALHO, C.H.S. Aspectos fisiológicos do crescimento e da produção do cafeeiro. IN: CARVALHO, C.H.S. (Ed.). Cultivares de Café origem, características e recomendações. Brasília:Embrapa Café, 2008. p.59-68.

MAZZAFERA, P.; CARVALHO, A. Produção e tolerância à seca de cafeeiros. Bragantia, v.46, p.403-415, 1987.

MEDINA-FILHO, H.P.; BORDIGNON, R.; CARVALHO, C.H.S. Desenvolvimento de novas cultivares de Café Arábica. IN: CARVALHO, C.H.S. (Ed.). Cultivares de Café. Brasília:Embrapa Café, 2008. p.79-102.

MOHAMMDKHANI, N.; HEIDARI, R. Water stress induced by polyethylene glycol 6000 and sodium chloride in two maize cultivars. Pakistan Journal Biological Sciences, v.11, p.92-97, 2008. http://www.pjbs.org

MUSCOLO, A.; SIDARI, M.; ANASTASI, U.; SANTONOCETO, C.; MAGGIO, A. Effect of PEG-induced drought stress on seed germination of four lentil genotypes. Journal of Plant Interactions, v.9, p.354-363, 2014. http://dx.doi.org/10.1080/17429145.2013.835880.

NASCIMENTO, M.N.; ALVES, J.D.; SOARES, A.M.; CASTRO, E.M.; MAGALHÃES, M.M.; ALVARENGA, A.A.; SILVA, G.H. Alterações bioquímicas de plantas e morfológicas de gemas de cafeeiro associadas a eventos do florescimento em resposta a elementos metereológicos. Ciência Rural, v.38, p.1300-1307, 2008. http://www.scielo.br/pdf/cr/v38n5/a15v38n5.pdf.

NONOGAKI, H.; BASSEL, G.W.; BEWLEY, J.D. Germination - Still a mystery. Plant Science, v.179, p.574-581, 2010. journal homepage: www.elsevier.com/locate/plantsci

PELEGRINI, L.L.; BORCIONI, E.; NOGUEIRA, A.C.; KOEHLER, H.S.; GERMAINE, M.; QUOIRIN, G. Efeito do estresse hídrico simulado com $\mathrm{NaCl}$, manitol e PEG (6000) na germinação de sementes de Erythrina falcata benth. Ciência Florestal, v.23, p.511-519, 2013. http://www.scielo.br/pdf/cflo/v23n2/1980-5098cflo-23-02-00511.pdf.
REFKA, Z.; MUSTAPHA, K.; ALI, F. Seed germination characteristics of Rhus tripartitum (Ucria) Grande and Ziziphus lotus (L.): Effects of water stress. International Journal of Ecology, v.2013, p.1-7, 2013. http://dx.doi.org/10.1155/2013/819810.

REGO, S.S.; FERREIRA, M.M.; NOGUEIRA, A.C.; GROSSI, F. Influência de potenciais osmóticos na germinação de sementes de Anadenanthera colubrina (Veloso) Brenan (Angico-branco) Mimosaceae. Revista Brasileira de Biociências, v.5, p.549-551, 2007.

REIS, R.C.R.; DANTAS, B.F.; PELACANI, C.R. Mobilization of reserves and germination of seeds of Erythrina velutina Willd. (Leguminosae - Papilionoideae) under different osmotic potentials. Revista Brasileira de Sementes, v.34, p.580-588, 2012. http://www. scielo.br/pdf/rbs/v34n4/08.pdf

SANTOS, R.F.; CARLESSO, R. Déficit hídrico e os processos morfológico e fisiológico das plantas. Revista Brasileira de Engenharia Agrícola e Ambiental, v.2, p.287-294, 1998.

VADEZ, V. Root hydraulics: The forgotten side of roots in drought adaptation. Field Crops Research, v.165, p.15-24, 2014. http:// ac.els-cdn.com/S0378429014000872/1-s2.0-S0378429014000872main.pdf?_tid=a58a8b16-0f2c-11e7-87d2-00000aab0f6b\&acdnat=1 490207188_5e7534acd248698395fb78b6c1fd40ee.

VADEZ, V.; KHOLOVA, J.; ZAMAN-ALLAH, M.; BELKO, N. Water: the most important 'molecular' component of water stress tolerance research. Functional Plant Biology, v.40, p.1310-1322, 2013. http://dx.doi.org/10.1071/FP13149.

VERSLUES, P.E.; JUENGER, T.E. Drought, metabolites, and Arabidopsis natural variation: a promising combination for understanding adaptation to water-limited environments. Current Opinion in Plant Biology, v.14, p.240-245, 2011. http://ac.els-cdn. com/S1369526611000586/1-s2.0-S1369526611000586-main.pdf? $\mathrm{tid}=699 \mathrm{ca} 4 \mathrm{~d} 4-0 \mathrm{f} 2 \mathrm{e}-11 \mathrm{e} 7-9 \mathrm{~d} 13-00000 \mathrm{aacb} 35 \mathrm{e} \& \mathrm{acdnat}=14902079 \overline{4}$ 7_75b45b6969b06cb74a87a545ee84a29d

VELAZQUEZ-MARQUEZ, S.; CONDE-MARTÍNEZ, V.; TREJO, C.; DELGADO-ALVARADO, A.; CARBALLO, A.; SUAREZ, R.; MASCORRO, J.O.; TRUJILLO, A.R. Effects of water deficit on radicle apex elongation and solute accumulation in Zea mays L. Plant Physiology and Biochemistry, v.96, p.29-37, 2015. https://doi. org/10.1016/j.plaphy.2015.07.006.

ZHU, J.; KANG, H.; TAN, H.; XU, M.J. Effects of drought stresses induced by polyethylene glycol on germination of Pinus sylvestris var. mongolica seeds from natural and plantation forests on sandy land. Journal Forest Research, v.11, p.319-328, 2006. https://link. springer.com/journal/10310/11/5/page/1 